\title{
10. Getting Rich after Getting Old: China's demographic and economic transition in dynamic international context
}

\section{Lauren Johnston, Xing Liu, Maorui Yang and Xiang Zhang ${ }^{1}$}

\section{Introduction}

When incomes and living standards rise, households tend towards having fewer children, inducing a fall in the population growth rate. This is a pattern evident in the historical development of many countries once they have progressed beyond the Malthusian poverty trap (Day and Dowrick 2004). The resulting transition produces population ageing - a process whereby the proportion of old people within the total population increases (ILO 2009).

In developing Asia in the post-Global Financial Crisis period, the speed of population ageing is among the biggest, if not the biggest, medium-term structural challenges (Park et al. 2012: xiii). The advent of ageing on such a scale is unprecedented. Population ageing affects considerably how economies behave (Stephenson and Scobie 2002). Changes affect aggregate economic and demographic characteristics, including the relative number of people who are dependent or working age, capacity for work, productivity, income distribution and investment. (Clark et al. 1978: 920).

Ageing of the population is typically measured with one or more of the following indicators:

1. greater than 7 per cent of the population aged over 65

2. less than 30 per cent of the population aged under 14

3. the ratio of old and young - as defined by (1) and (2) - exceeding 0.3

4. a median age more than 30 (Siegel 1980).

1 Lauren Johnston is a Research Fellow at the Melbourne Institute of Applied Economic and Social Research, Faculty of Business and Economics, University of Melbourne. Email: lauren.johnston@unimelb.edu.au. Xing Liu, Maorui Yang and Xiang Zhang are Research Fellows at the China Center for Health Economic Research, National School of Development, Peking University. The authors wish to thank Professors Ross Garnaut and Gordon Liu for their helpful comments on an early draft of this chapter, and also a 2015 Dyason Fellowship awarded by the University of Melbourne to support this research collaboration. 
The first is the most commonly used simple indicator of population ageing and is used to empirically define an ageing population herein.

In 2014, there were 590 million people aged over 65 in a global population of 7.26 billion people - some 8.1 per cent (World Bank 2015). China's population has been classified as 'ageing' since 2000, the year the population share of those aged 65 and older reached 7 per cent. By 2014, this share had reached 9.2 per cent, or 130 million people in the total Chinese population of 1.36 billion (World Bank 2015). More than one-third of countries now host ageing populations. Figure 10.1 highlights the spatial distribution of ageing across countries in 2014 and shows there is much variation (İmrohoroğlu 2007: 148).

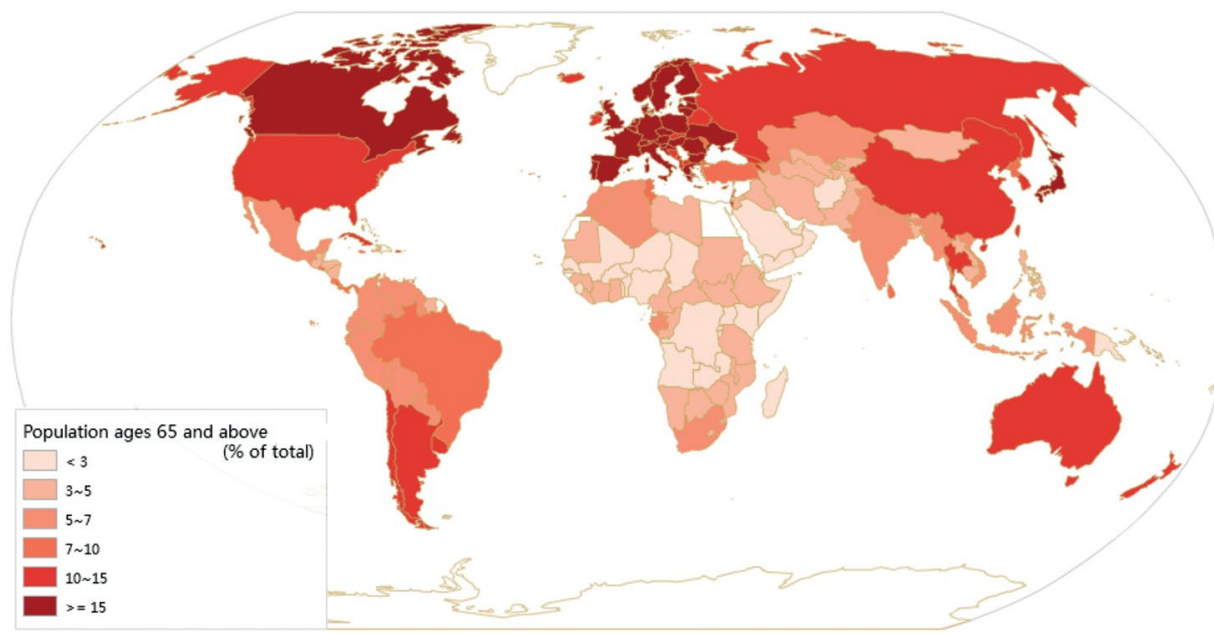

Figure 10.1 Share of population aged 65 years and older, 2014

Sources: World Bank (2015); UN (2015).

National ageing population intensity and regional density are highest in the high-income countries of Western Europe, North America and North-East Asia (Figure 10.1). Populations that were first to age among these countries are broadly shaded a dark red in Figure 10.1, and were typically developed economically before becoming 'old'. Many of the 48 countries that have joined the 'ageing' group since 1960, however, especially in East Asia, were developing countries when they reached the ageing threshold (World Bank 2015). Each 'ageing' country faces a unique mix of ageing-related challenges (Park et al. 2012: xiv), reflecting differences in behaviour across individuals and countries over the life cycle, combined with an increase in the relative number of older people (Clark et al. 1978: 949). 
Studies of population ageing are divided roughly into three categories. Studies of:

- macroeconomic problems related to the decline in the workforce due to ageing

- social security systems, with many looking at pension systems

- the microeconomics of the labour market - for example, employment of the elderly, competition with younger workers, the female workforce and immigrant workers (Onofri 2004).

A prescient empirical study falling into the first category, published some two decades before China's population crossed into the 'ageing' category, predicted that China would face the challenge of ageing before its economy reached highincome per capita levels of gross domestic product (GDP) (Wu 1986).

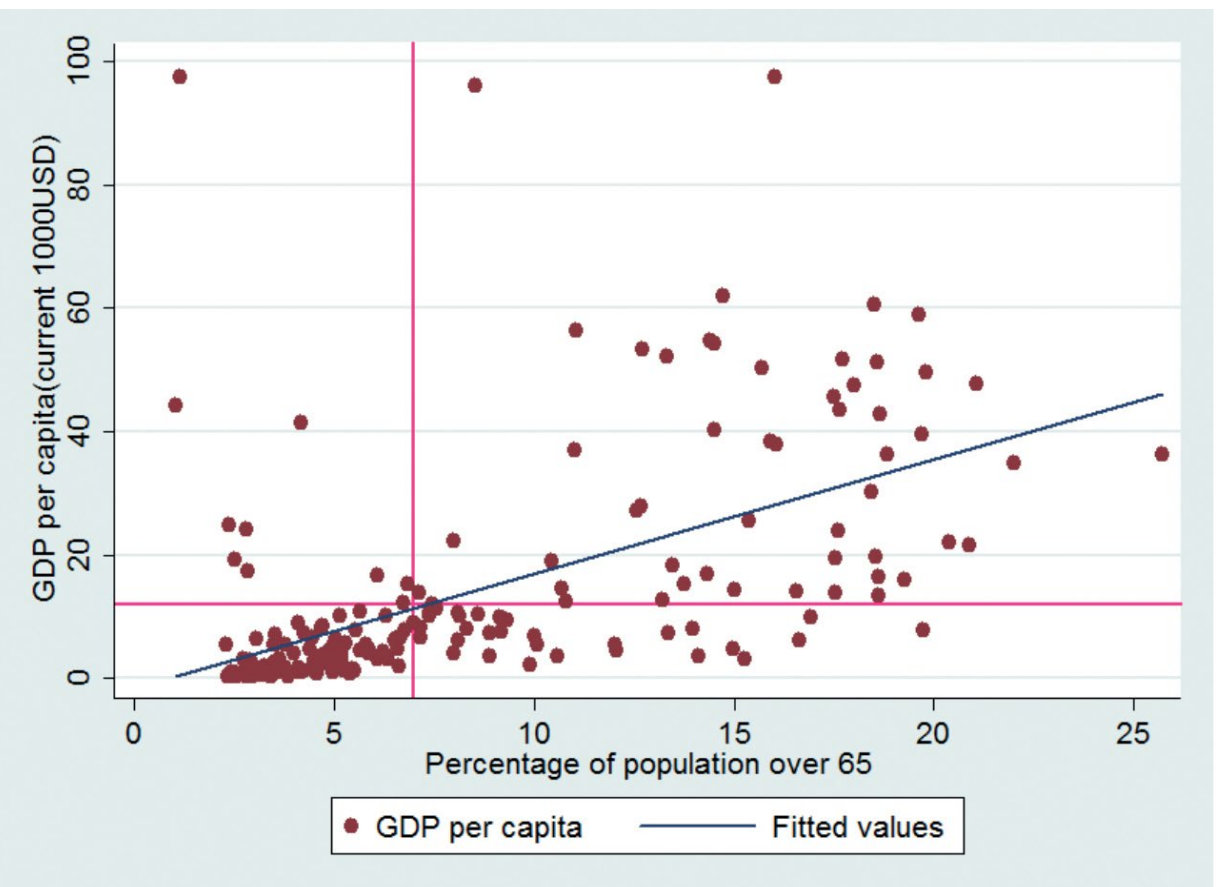

Figure 10.2 Population ageing share and income per capita, 2014 Source: World Bank (2015).

Figure 10.2 places countries into one of four categories, depending on the proportion of old people in the population and GDP per capita. China is placed in the less densely populated bottom right-hand rectangle-among countries with a share of population aged 65 and over above 7 per cent that in 2014 also had an income below the high-income threshold of $\$ 12,616$ current international 
dollars (World Bank 2015). Wu (1986) argued that carrying such an elderly dependency weight at an early stage of development - a pattern he described as 'getting old before rich' (GOBR) - would inhibit China from joining the highincome developed group of countries. Wu (1986) focused on China. Here, we draw attention to the fact that other economies confront variants of the same challenge.

Cai and Wang (2007: 86) summarise the risk China's 'premature' ageing may bring in terms of the fact that loss of labour factor endowment advantages arrives ahead of new advantages in capital-intensive and technology-intensive industries (Cai 2010). The importance relates to the relationship between population and capital, which is explained in the Solow growth model. In Solow, where $n$, the rate of growth of the total workforce (L), becomes negative, capital (K) per worker $(\mathrm{k})$ increases due to the decrease in L. This causes increases in wages and growth in output $(\mathrm{Y})$ per worker $(\mathrm{y})$, but fewer workers as a proportion of the population. Whether the shift in output per worker is greater or less than the shift in the workers' share of the population is exogenously determined.

Using a Solow framework, Wang et al. (2004) find that population ageing in China could affect economic growth via labour supply, the savings rate (through population ageing inducing changes in both consumption and savings) and through a slower rate of technological advancement. Hu et al. (2012) adopt a Solow growth model to reach similar conclusions using provincial-level panel data. Golley and Tyers (2012) use active workforce statistics rather than working-age population figures to estimate that China will enjoy a demographic dividend through to 2030 . In general, however, cross-country studies of China's relative ageing challenges are few. Moreover - and remarkably given that GOBR is a relative concept - there are few studies that have explored China's ageing relatively, notable recent exceptions being the World Bank (2015) and Park et al. (2012).

Thirty years since Wu (1986), this chapter re-examines China's ageing challenge around the GOBR notion. For the first time in the literature, to our knowledge, this includes an extension of Wu's framework (1986) to the full four-state comparative framework that is implicit in the GOBR idea. The goal here is twofold:

1. To create a framework that places China's ageing challenge in an international context.

2. To draw greater attention to diversity among ageing populations and to their economic context, with various implications for policy.

China is just one of many countries navigating the process of economic development under GOBR conditions. It also identifies a prospectively useful reference point: several middle-income countries with ageing populations have in recent years successfully transitioned from being 'poor' to being 'rich'. Our 
analysis suggests that China's chances of making a successful transition to highincome status after growing old may be better than Chinese consensus has expected. China's 'fear of ageing' (Calvo and Reinhart 2002) may have prepared it well, but it could also be reducing the focus on positive opportunities attached to its ageing-wealth nexus, such as being able to define more sustainable ageingrelated entitlements. Importantly, our results also infer that, in the absence of oil wealth, recent experience is that countries are more likely to move from middle into high per capita income status after entering the 'old' category.

The rest of this chapter is structured as follows. The second section describes the basic empirical measures of China's ageing population. The third section presents an extension of $\mathrm{Wu}$ (1986) using a transitions matrix approach. The fourth section compares economic structure across GOBR countries. The final section discusses the contents of this survey and proposes areas for future research.

\section{Population ageing in China: Empirical survey}

This section presents an overview of China's ageing-related indicators, including the total fertility rate, life expectancy and population share of those aged 65 and over, and the concept of 'ageing duration'. The section also defines and discusses issues in China's total, youth and elderly dependency ratios. The total fertility rate refers to the expected number of children a woman who survives to the end of the reproductive age span will have during her lifetime if she experiences given age-specific rates of childbirth (UNDATA 2016).

Table 10.1 Basic ageing population empirics, China

\begin{tabular}{|l|r|r|r|r|}
\hline & $\begin{array}{c}\text { Total fertility } \\
\text { rate* }\end{array}$ & $\begin{array}{c}\text { Life expectancy } \\
\text { at birth (years) }\end{array}$ & $\begin{array}{c}\text { Share of population aged } \\
\text { 65 and over (\% of total) }\end{array}$ & $\begin{array}{c}\text { Number of people } \\
\text { aged 65 and over }\end{array}$ \\
\hline 1980 & 2.7 & 67 & 4.5 & $44,155,575$ \\
\hline 1990 & 2.5 & 69.5 & 5.3 & $60,164,805$ \\
\hline 2000 & 1.5 & 72.1 & 6.7 & $84,597,215$ \\
\hline 2010 & 1.7 & 74.9 & 8.2 & $109,691,810$ \\
\hline 2014 & 1.6 & 75.8 & 9.2 & $125,512,840$ \\
\hline
\end{tabular}

* Excludes data for Hong Kong SAR, Macau SAR and Taiwan.

Source: World Bank (2015).

Table 10.1 presents selected ageing population indicators over recent decades. The data show that China's total fertility rate fell by nearly half in the last two decades of the past century, before lifting a little, and life expectancy increased by nearly a decade over three decades. These developments underlie the rise 
in the population share of people aged over 65 , from 4.5 to 9.2 per cent. Home to the world's largest population, China is now also home to the world's largest stock of old people - some 125 million in 2014. By population share of people aged 65 and over, however, China's rank was just 65th in the same year (World Bank 2015). In other words, China is an outlier in the number but not the share of old people.

A commonly used empirical indicator is the dependency ratio, which is defined as the ratio of population aged 0-14 years and 65 years and over per 100 people aged 15-64. The United Nations uses a medium fertility variant to calculate the total dependency ratio, alongside child and elderly dependency ratios (UN 2002). China's total dependency ratio declined rapidly over the last quarter of the past century, providing a substantial 'demographic dividend' (Figure 10.3). In China's case, it is calculated that for every 1 per cent fall in the dependency ratio resulting from an expanding workforce share, GDP per capita increased by 0.115 per cent (Cai 2010).

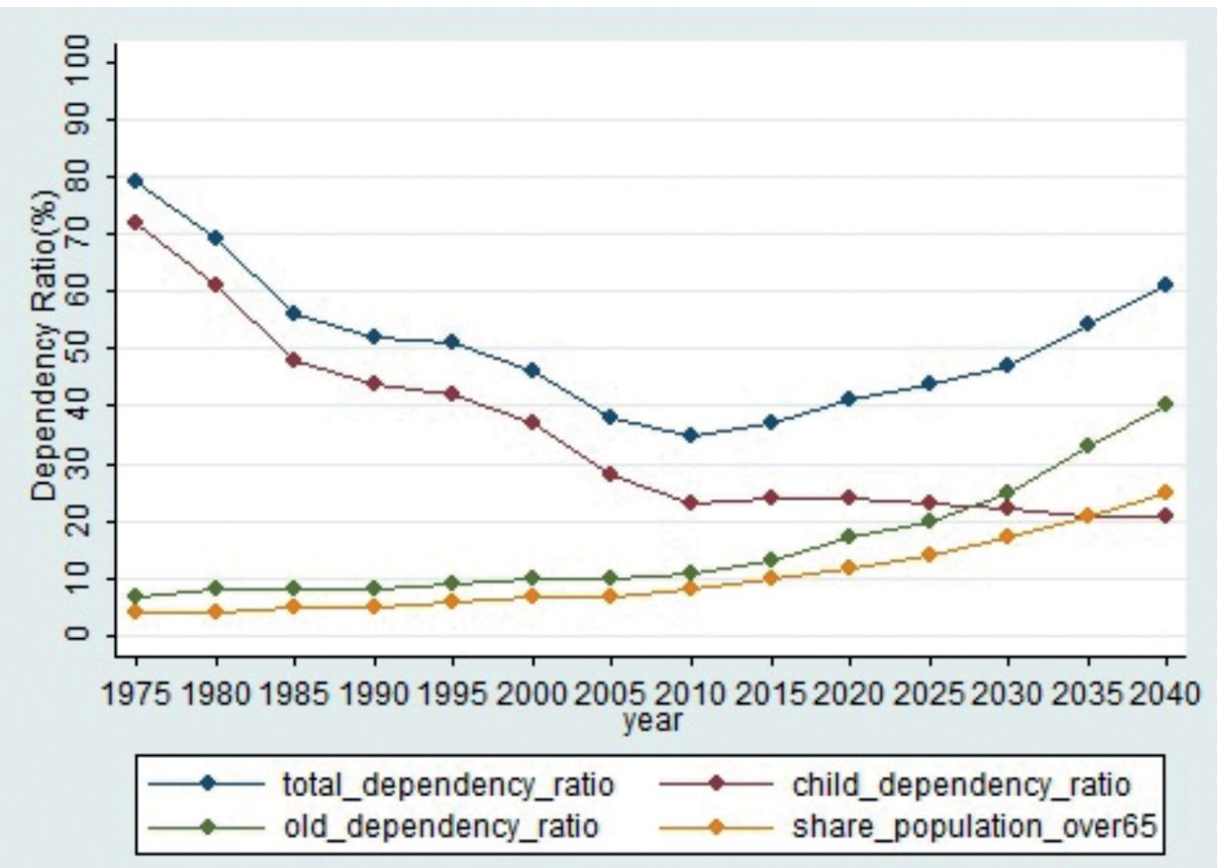

Figure 10.3 Total, child and elderly dependency ratios, China Source: UN (2015).

A halt in the decline of the total dependency ratio reflects the end of the main demographic dividend (Minami 1968, cited in Cai 2010). The Lewis model reflects a related concept focused on how the incremental transfer of surplus labour from low productivity rural areas into higher productivity urban and 
industrial sectors drives industrialisation via growth in average productivity and total output (Garnaut 2010). Eventually, however, the surplus rural labour dries up - a point known as the Lewis turning point. As illustrated in Figure 10.3, in China this happened about 2009 (Garnaut 2010: 8). The proximity of the arrival of the Lewis turning point to the onset of population ageing varies between countries. Recent family planning policies cause the two turning points to be unusually close in China. This compounds the rate of increase in labour scarcity and wage pressures, and increases the challenges of the transition to a new growth model.

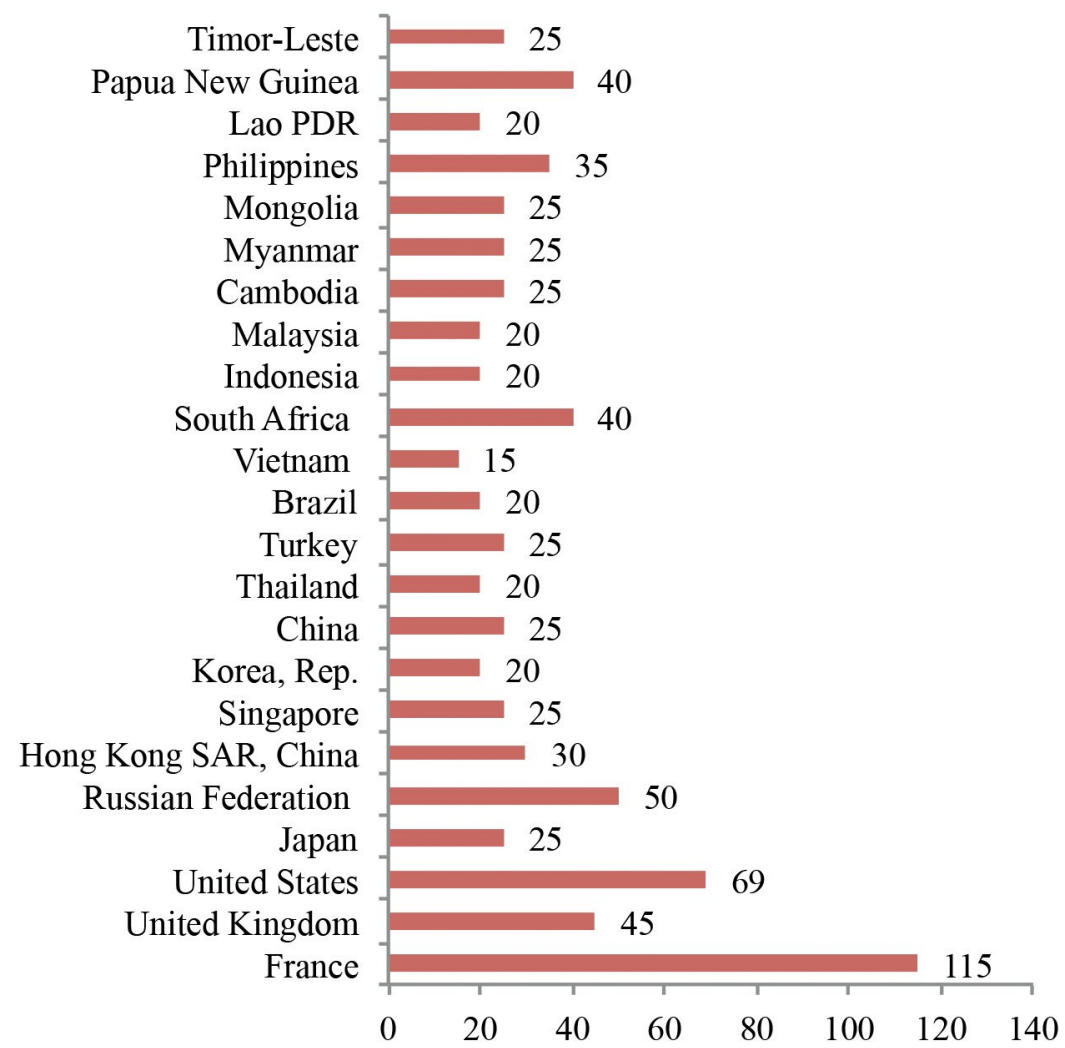

Figure 10.4 Years taken for ageing share to increase from 7 to 14 per cent of population

Note: Countries reaching 7 per cent the earliest are at the bottom of the graph, with countries ageing later at the top.

Sources: World Bank (2016).

China's geographically differentiated labour market means, however, that the end of the demographic dividend is less of a 'turning point' and more of a 'turning period' during which wages will rise as labour becomes scarce (Garnaut 2010: 6). 
Several factors can shift the length of the 'turning period' including the speed of ageing and educational attainment. The ease with which the transition to a new steady state built on higher productivity and higher wages occurs relates to the efficiency of institutions. The time these institutions have had to prepare for managing the consequences of ageing populations is partly a function of the speed of the demographic transition.

A particular feature of contemporary global population ageing is its increasing speed (Lutz et al. 2008). While, for example, it took France more than a century for the percentage of people aged 65 and over to increase from 7 per cent to 14 per cent of the total population, the equivalent ageing transition is now happening within a generation in some less-developed countries (Powell and Cook 2009: 390) (Figure 10.4). East Asia and the Pacific are now ageing faster than any region in history, with nearly all middle-income countries in the region currently in or about to experience a process of rapid population ageing. Figure 10.4 illustrates the point. While it took France, for example, 115 years to shift from having 7 per cent of the population aged 65 and over to 14 per cent, Vietnam has taken just 15 years to do the same. In other words, and in parallel with the region's economic transformation, demographic transitions that took some 100 years in founding Organisation for Economic Co-operation and Development (OECD) countries are happening in 20-25 years in some middleincome countries (World Bank 2015).

In the Chinese literature, $\mathrm{Wu}$ and $\mathrm{Du}$ (2006) note the importance of 'ageing duration', which is defined as the length of time a country has been classified as having an ageing population. They argue that China's ageing challenge should only be compared with that of countries with a similar ageing duration. Their argument relates to fears that countries with a short ageing duration have had little time to prepare and, in the case of developing countries, this is compounded by the lesser availability of resources per capita (Park et al. 2012: 9).

The experience of China and other East Asian countries can be contrasted with that of countries with a long 'ageing duration'-notably, those in Western Europe, where 'wealth duration' is long: 'getting old after getting rich' (GOAR). In GOAR countries, it is more likely that the entitlements of the old-having been defined over a long period when they represented a smaller share of the population and when life expectancy after retirement was some decade shorter than today - will turn out to be unsustainable in modern conditions. The relative 'fear of ageing' (Calvo and Reinhart 2002) in newly ageing developing economies (GOBR), especially China, would seem to be misplaced. The GOBR countries may be better placed than others to install fiscally sustainable retirement policies. 
The channels through which population ageing affects a population's productive power, consumption patterns and investment and political behaviours require more study (Eisele 1974: 77). This chapter offers a simple extension of Wu (1986) to elaborate China's prospects for a smooth transition to high-income status after getting old. This draws attention to the possibility that structural risks attached to ageing in rich countries may require more attention in policy development. The next section revisits and extends Wu (1986).

\section{Extended Wu demographic-income framework}

\section{Extended Wu framework}

The GOBR (Wu 1986) notion has served as a reference point in the academic literature in China for three decades. Despite being an implicitly comparative idea, Wu's logic has not been developed within the ageing income framework that it implies.

Table 10.2 Extrapolated Wu framework

\begin{tabular}{|l|l|c|c|}
\hline \multicolumn{2}{|c|}{} & \multicolumn{2}{|c|}{ Population } \\
\cline { 2 - 4 } \multicolumn{2}{|c|}{} & Old & \multicolumn{1}{c|}{ Young } \\
\hline \multirow{3}{*}{ GDP per capita } & High (rich) & Ageing after rich $(\mathrm{RO})$ & Rich and youth-filled (RY) \\
\cline { 2 - 4 } & Low/middle (poor) & Ageing before rich $(\mathrm{PO})$ & Poor and youth-filled (PY) \\
\hline
\end{tabular}

$\mathrm{RO}=$ 'rich and old'

$\mathrm{PO}=$ 'poor and old'

$\mathrm{RY}=$ 'rich and young'

PY = 'poor and young'

Table 10.2 outlines the three parallel states that are implied by 'getting old before getting rich' (Wu 1986): 'getting old after getting rich' (Johnston 2012), 'rich and youth-filled' and 'poor and youth-filled'. That China falls into the 'poor-old' (PO) category is empirically established in the Chinese literature (see sections one and two of this chapter). 
Table 10.3 Selected countries, extended Wu framework, 2014

\begin{tabular}{|l|l|l|l|}
\hline \multicolumn{2}{|c|}{} & \multicolumn{2}{c|}{ Population } \\
\cline { 3 - 4 } & \multicolumn{1}{|c|}{ Old } & \multicolumn{1}{c|}{ Young } \\
\hline \multirow{2}{*}{$\begin{array}{l}\text { GDP per } \\
\text { capita }\end{array}$} & $\begin{array}{l}\text { High } \\
\text { (rich) }\end{array}$ & $\begin{array}{l}\text { Australia, Chile, Hong Kong SAR, } \\
\text { Korea Rep., Israel, Italy, Poland } \\
\text { Russia, Singapore, Slovenia, USA, } \\
\text { Uruguay }\end{array}$ & $\begin{array}{l}\text { Bahrain, Brunei, Equatorial } \\
\text { Guinea, Kuwait, Qatar, } \\
\text { Seychelles, Saudi Arabia, UAE }\end{array}$ \\
\cline { 2 - 4 } & $\begin{array}{l}\text { Low/middle } \\
\text { (poor) }\end{array}$ & $\begin{array}{l}\text { Brazil, Argentina, China, Lebanon, } \\
\text { Mauritius, Panama, Romania, } \\
\text { Sri Lanka, Thailand, Turkey, Ukraine }\end{array}$ & $\begin{array}{l}\text { Ecuador, Egypt, India, Indonesia, } \\
\text { Kenya, Libya, Malaysia, Mexico, } \\
\text { South Africa, Vietnam }\end{array}$ \\
\hline
\end{tabular}

In Table 10.3, the country examples presented are from a population study listed in Appendix Table A11.1. Economies were classified into the extended $\mathrm{Wu}$ framework using the empirical definition of aged used throughout this chapter: a 7 per cent or higher population share of those aged 65 and over. The definition of 'rich' refers to the World Bank's high-income classification of gross national income (GNI) per capita of more than $\$ 12,616$ current international dollars in 2014.

The overall distribution of countries between the four categories over time (see Appendix Table Al1.1) can be summarised simply as follows. The rich and old (RO) are mostly OECD countries. Poor and old (PO) countries are mostly 'transitional economies' - Eastern European countries and China - or countries stuck in the 'middle-income trap' such as Brazil and Peru. Rich and youth-filled (RY) countries are mostly members of the Organization of the Petroleum Exporting Countries (OPEC). Finally, poor and youth-filled (PY) countries are most of the world's low-income countries and selected middle-income countries. The average share of the population aged 65 and over in RO countries is 16 per cent, compared with 11 per cent for PO countries (Appendix Table A11.2). RY countries are younger on average than PY countries: 3.4 per cent compared with 4.1 per cent. The relative average per capita income gap between PY and PO countries also appears to be substantial. This relates to the 'poor' category covering both low and middle-income economies. This point will be further explored below.

The numbers by category are presented in Table 10.4 in selected years. Note that China became an ageing population in 2000. In general, the data suggest that populations are shifting from young to old at a faster rate than they are shifting from poor to rich. In 1990, of 172 countries, 59 were old (34 per cent) and 53 rich (31 per cent). By 2014, the share of rich countries remained at 31 per cent, but the share of old countries had increased to 47 per cent. 
Table 10.4 Countries by category, selected years*

\begin{tabular}{|l|r|r|r|r|r|r|r|r|}
\hline \multirow{2}{*}{ Category } & \multicolumn{2}{|c|}{1990} & \multicolumn{2}{c|}{2000} & \multicolumn{2}{|c|}{2010} & \multicolumn{2}{|c|}{2014} \\
\cline { 2 - 9 } & No. & \multicolumn{1}{c|}{$\%$} & \multicolumn{1}{c|}{ No. } & \multicolumn{1}{c|}{$\%$} & \multicolumn{1}{c|}{ No. } & \multicolumn{1}{c|}{$\%$} & No. & \multicolumn{1}{c|}{$\%$} \\
\hline RO & 31 & 18.0 & 37 & 19.9 & 46 & 24.6 & 46 & 25.7 \\
\hline PO & 17 & 9.9 & 30 & 16.1 & 29 & 15.5 & 28 & 15.6 \\
\hline RY & 17 & 9.9 & 8 & 4.3 & 11 & 5.9 & 9 & 5.0 \\
\hline PY & 107 & 62.2 & 111 & 59.7 & 101 & 54.0 & 96 & 53.6 \\
\hline Total & 172 & 100 & 186 & 100 & 187 & 100 & 179 & 100 \\
\hline Old & 59 & 30.1 & 69 & 35.2 & 81 & 41.1 & 85 & 43.4 \\
\hline Rich & 53 & 29.1 & 53 & 26.5 & 63 & 32.0 & 56 & 30.3 \\
\hline
\end{tabular}

* Countries with missing values: 45 in 1990; 32 in 2000; 31 in 2010; 40 in 2014.

In the next section, we explore this movement more directly using a transition matrix analysis. In 2014, China was one of 28 countries confronting the GOBR challenge. There were 31 such countries in 2010. Some countries are moving between the groups over time. Further study of those transitions and the important institutions and policies underlying them, especially in the case of a successful transition from the PO to the RO category - China's contemporary economic goal—could offer useful insight for Chinese policymakers.

\section{Extended Wu framework transition matrix}

To explore country transitions within our extended Wu framework, we retain our definition of 'old' as a 7 per cent share in population of those aged 65 and older, and of 'rich' as the World Bank's high-income classification. We take the World Bank high-income classification in current international dollars over time as follows: GDP per capita of more than $\$ 6,000$ in $1990, \$ 9,361$ in $2000, \$ 11,906$ in 2010 and $\$ 12,616$ in 2014 . These intervals are selected so as to understand China's ageing in international context, as China moved into the 'old' category in 2000 and 2014 was the most recent year with widely available data.

Data are sourced entirely from the World Bank's World development indicators (2015). In 1990, 45 countries dropped from the country list because they missed one or both of the population or income data points. In 2000, that number was 31, 30 in 2010 and 38 in 2014. Countries also fell out of the sample if they were affected by conflict (for example, Iraq dropped from 2000, and Eritrea and Syria from 2014). Similarly, many of the countries emerging from the former Soviet Union had sufficient data to enter the study only in 2000 and not in 1990. As we are interested mainly in the share of countries moving between categories at different intervals, for the purpose of this chapter we decided to use the sample available at each interval rather than keeping a consistent sample throughout. 
Table 10.5 Transition matrix, 1990-2014 (number of countries)

\begin{tabular}{|l|l|r|r|r|r|}
\hline \multirow{4}{*}{1} & & \multicolumn{5}{|c|}{2014} \\
\cline { 2 - 6 } & Category & RO & PO & RY & PY \\
\hline \multirow{3}{*}{1990} & RO & 29 & 0 & 0 & 0 \\
\cline { 2 - 6 } & PO & 5 & 11 & 0 & 0 \\
\cline { 2 - 6 } & RY & 4 & 0 & 6 & 3 \\
\cline { 2 - 6 } & PY & 2 & 14 & 2 & 84 \\
\hline
\end{tabular}

$\mathrm{RO}=$ 'rich-old'

$\mathrm{PO}=$ 'poor-old'

$\mathrm{RY}=$ 'rich-young'

PY = 'poor-young'

Table 10.5 sets out a transition matrix $\mathrm{T}$, a $4 * 4$ matrix, where element $\mathrm{T}_{i, j}$ represents the number of countries grouped into category $i$ in 1990, and into category $j$ in 2014. Countries that did not change categories between the two intervals are located along the left-right diagonal line. The matrix reveals that no 'RO' country shifted between groups over the reference period. That is, all countries in the sample that were 'rich and old' in 1990 remained in the RO group in 2014. Most of the PY group also stayed poor and young.

Table 10.6 Transition matrix, 1990-2014 (percentage form)

\begin{tabular}{|l|l|r|r|r|r|}
\hline & & \multicolumn{5}{|c|}{2014} \\
\hline \multirow{3}{*}{1990} & Category & RO & PO & RY & PY \\
\cline { 2 - 6 } & RO & 100 & 0 & 0 & 0 \\
\cline { 2 - 6 } & PO & 31 & 69 & 0 & 0 \\
\cline { 2 - 6 } & RY & 31 & 0 & 46 & 23 \\
\cline { 2 - 6 } & PY & 2 & 14 & 2 & 82 \\
\hline
\end{tabular}

Source: Authors' own calculations using World Bank (2015) data.

Table 10.6 presents the percentages attached to the transitions of Table 10.5. The data show that the most likely transition is, in fact, from PO to RO - the very transition China is trying to make. Some 31 per cent of the 1990 PO group had transitioned to the RO group by 2014 , and 69 per cent remained in the PO group. That is, the transition to high per capita incomes appears to be more probable from a base of population ageing than from a young population. China's GOBR challenge may be easier to achieve than feared. 
On the other hand, more than half the 1990 PO group remained in the PO category nearly one-quarter of a century later, by 2014. Ageing is certainly not in and of itself a route to wealth. Moreover, 14 per cent of the countries in the 1990 PY group transitioned to the PO category by 2014. In the absence of oil wealth, getting old is still more probable than getting rich.

The 'poor' category is crude because it spans a wide array of economies - from dynamic upper-middle-income economies to least-developed economies. In the next step, we disaggregate the 'poor' category into 'low', 'middle' and 'upper' middle-income bands. The GNI per capita thresholds used for this were: in $1990, \$ 545, \$ 2,200$ and $\$ 6,000$; in 2000, $\$ 760, \$ 3,030$ and $\$ 9,361$; in 2010, $\$ 975$, $\$ 3,855$ and $\$ 11,906$; and, in 2014, \$1,035, \$4,085 and \$12,616 (World Bank 2015).

Table 10.7 Disaggregated transition matrix, 1990-2014 (number of countries)

\begin{tabular}{|c|c|c|c|c|c|c|c|c|c|}
\hline & & & \multicolumn{7}{|c|}{2014} \\
\hline & \multirow[t]{2}{*}{ Population } & & \multicolumn{3}{|c|}{ Old } & \multicolumn{4}{|c|}{ Young } \\
\hline & & Income & High & $\begin{array}{l}\text { Upper- } \\
\text { middle }\end{array}$ & $\begin{array}{l}\text { Lower- } \\
\text { middle }\end{array}$ & High & $\begin{array}{l}\text { Upper- } \\
\text { middle }\end{array}$ & $\begin{array}{l}\text { Lower- } \\
\text { middle }\end{array}$ & Low \\
\hline \multirow[t]{7}{*}{1990} & \multirow[t]{3}{*}{ Old } & High & 29 & 0 & 0 & 0 & 0 & 0 & 0 \\
\hline & & $\begin{array}{l}\text { Upper- } \\
\text { middle }\end{array}$ & 4 & 5 & 0 & 0 & 0 & 0 & 0 \\
\hline & & $\begin{array}{l}\text { Lower- } \\
\text { middle }\end{array}$ & 1 & 3 & 3 & 0 & 0 & 0 & 0 \\
\hline & \multirow[t]{4}{*}{ Young } & High & 4 & 0 & 0 & 6 & 3 & 0 & 0 \\
\hline & & $\begin{array}{l}\text { Upper- } \\
\text { middle }\end{array}$ & 2 & 5 & 0 & 1 & 7 & 0 & 0 \\
\hline & & $\begin{array}{l}\text { Lower- } \\
\text { middle }\end{array}$ & 0 & 5 & 1 & 0 & 16 & 23 & 2 \\
\hline & & Low & 0 & 1 & 1 & 1 & 0 & 14 & 22 \\
\hline
\end{tabular}

Table 10.7 presents the transitions between ageing and income groups where the 'poor' category is disaggregated into upper-middle, lower-middle and lowincome groups. A total of five countries that were already old in 1990 moved into the high-income group, one from lower-middle income and four from upper-middle-income country status. These countries offer a precedent for the transition China now seeks to make-from a middle-income economy with an ageing population to a high-income country with an ageing population. 
Table 10.8 Countries by transition

\begin{tabular}{|c|c|c|c|c|}
\hline \multicolumn{2}{|l|}{1990} & \multicolumn{2}{|l|}{2014} & \multirow[b]{2}{*}{ Country } \\
\hline Income & Demography & Income & Demography & \\
\hline \multirow[t]{4}{*}{ Low } & \multirow[t]{4}{*}{ Young } & Lower-middle & Young & $\begin{array}{l}\text { Bangladesh, Ghana, India, Kenya, } \\
\text { Kiribati, Lao PDR, Mauritania, } \\
\text { Nicaragua, Nigeria, Pakistan, } \\
\text { Sudan, Tajikistan, Vietnam, Zambia }\end{array}$ \\
\hline & & Lower-middle & Old & Sri Lanka \\
\hline & & Upper-middle & Old & China \\
\hline & & High & Young & Equatorial Guinea \\
\hline \multirow{5}{*}{$\begin{array}{l}\text { Lower- } \\
\text { middle }\end{array}$} & \multirow[t]{3}{*}{ Young } & Low & \multirow[t]{2}{*}{ Young } & Comoros, Zimbabwe \\
\hline & & \multirow[t]{2}{*}{ Upper-middle } & & $\begin{array}{l}\text { Azerbaijan, Colombia, Dominican } \\
\text { Republic, Ecuador, Fij, Jordan, } \\
\text { Kazakhstan, Maldives, Namibia, } \\
\text { Paraguay, Peru, Samoa, Suriname, } \\
\text { Tonga, Turkmenistan }\end{array}$ \\
\hline & & & Old & $\begin{array}{l}\text { Albania, El Salvador, Lebanon, } \\
\text { Thailand, Tunisia }\end{array}$ \\
\hline & \multirow[t]{2}{*}{ Old } & High & \multirow[t]{2}{*}{ Old } & Poland \\
\hline & & Upper-middle & & Belarus, Jamaica, Romania \\
\hline \multirow{3}{*}{$\begin{array}{l}\text { Upper- } \\
\text { middle }\end{array}$} & \multirow[t]{2}{*}{ Young } & High & \multirow[t]{2}{*}{ Old } & Chile, Trinidad and Tobago \\
\hline & & Upper-middle & & $\begin{array}{l}\text { Brazil, Costa Rica, Mauritius, St } \\
\text { Vincent and the Grenadines, Turkey }\end{array}$ \\
\hline & Old & High & Old & $\begin{array}{l}\text { Czech Republic, Russian } \\
\text { Federation, Slovakia Republic, } \\
\text { Uruguay }\end{array}$ \\
\hline \multirow[t]{2}{*}{ High } & \multirow[t]{2}{*}{ Young } & Upper-middle & Young & Gabon, Iraq, Libya \\
\hline & & High & Old & $\begin{array}{l}\text { Bahamas, Korea Rep., Macau SAR } \\
\text { (China), Singapore }\end{array}$ \\
\hline
\end{tabular}

Note: Countries with average per capita incomes that have transitioned to lower income groups are in italics.

Source: Authors' own calculations using World Bank (2015).

Table 10.8 elaborates ageing and income group transition by country across the years 1990 to 2014. These pathways have not previously been analysed. The data show that China has, since 1990, been alone in its transition pathway-from a low-income and young country to an upper-middle income and old country. Several countries have made different transitions-for example, Albania, El Salvador, Lebanon, Thailand and Tunisia have transitioned from lower-middle income and youth-filled to upper-middle income and old. Belarus, Jamaica and Romania were already old in 1990, and transitioned from lower-middle income 
to upper-middle income and old. Brazil, Costa Rica, Mauritius, Saint Vincent and the Grenadines and Turkey, on the other hand, transitioned from youthfilled to old without a shift between income groups.

It is also interesting to draw parallels between China and the countries that have recently transitioned to the 'rich' category. Among them, Equatorial Guinea, an oil-rich state in Africa, is alone in not also having moved to an ageing population. Two countries managed the transition from upper-middle income and youthfilled to high-income and old: Chile and Trinidad and Tobago. In 1990, Poland was already 'old', but managed to transition from lower-middle income to high income by 2014 .

The countries that have already successfully transitioned from upper-middle income to high income status with an ageing population-the transition China seeks to make - are Uruguay, Czech Republic, Russian Federation and the Slovakia Republic. By comparison, the final row of Table 10.8 highlights that China's East Asian neighbours have populations that recently entered the 'ageing' category, while having already joined the high-income club: South Korea, Macau SAR (China) and Singapore. These countries are cases of GOAR. In other words, in earlier years it was common to transition into the highincome category from a youthful population base, but this pattern appears to be shifting towards one in which an ageing population is a more likely lift-off point. Lessons for China's transition can be drawn from both sets of experiences.

\section{Getting rich after getting old: Comparisons}

Factors associated with a successful transition from middle to high per capita income include a relatively high level of secondary and tertiary education and a relatively high share of high-technology products within exports (Eichengreen et al. 2014). Cai (2012) argues that for China to avoid the middle-income trap it must: 1) transform economic growth to a consumption-driven pattern; 2) shift labour-intensive industries to central and western regions of the country; and 3) speed up technological catch-up. The current Five-Year Plan (FYP) broadly addresses these challenges. 


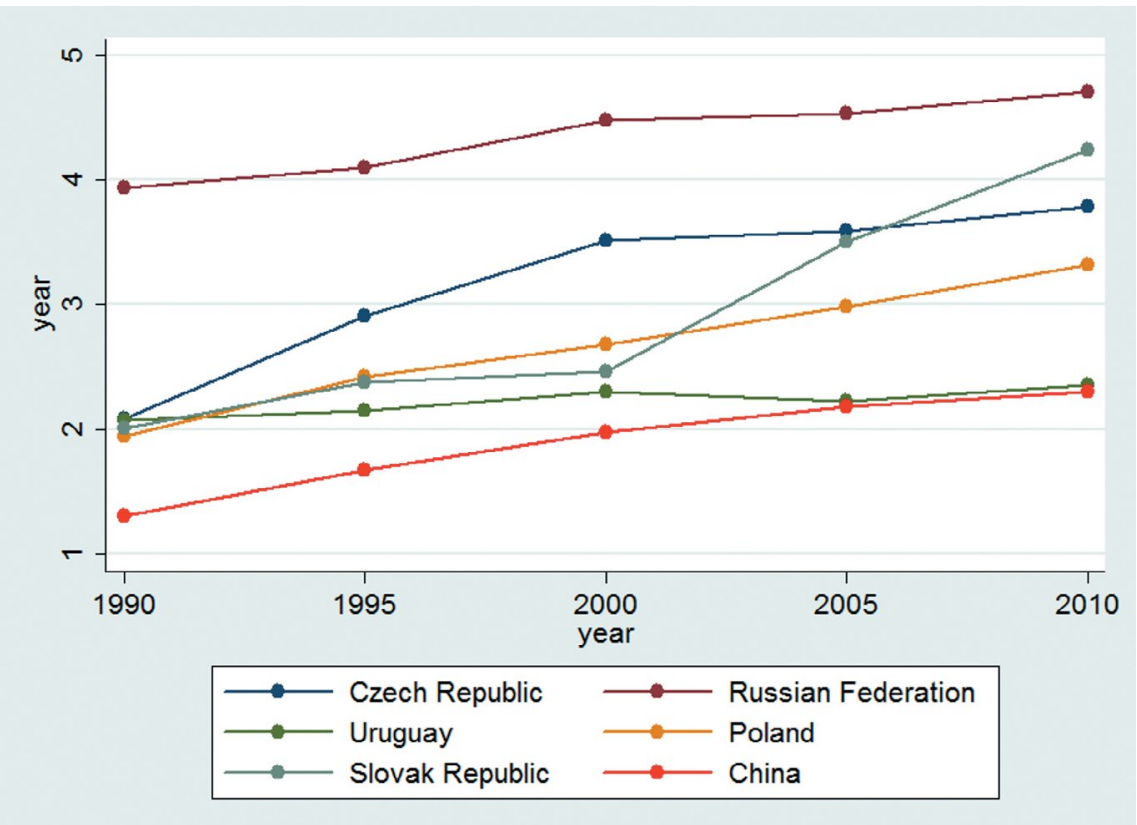

Figure 10.5 Average total years of secondary schooling, age 15+, total, in China compared with countries that were PO before RO

Source: Barro and Lee (2013).

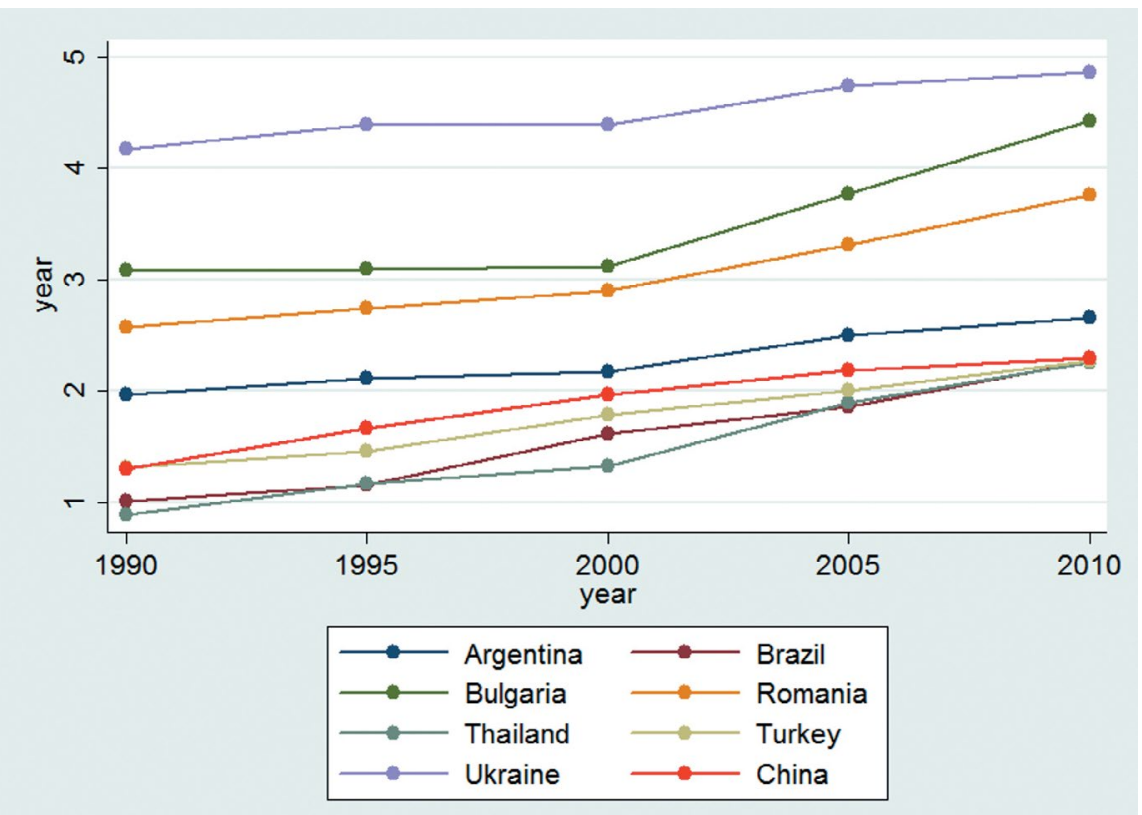

Figure 10.6 Average total years of secondary schooling, age 15+, total, in China compared with countries remaining in a PO state 
With regard to Eichengreen et al.'s (2014) contention that high education levels are the first necessary factor for successful transition to high per capita income, average years of secondary schooling remain low in China compared with countries that have recently succeeded in moving from the middle-income to the high per capita income group (Figure 10.5). Under the Thirteenth FYP, China is, however, increasing efforts to popularise high school education. A recent World Bank report (2016: 11) suggests that there is reason for cautious optimism about rising education rates in East Asia, with increasingly educated cohorts being better prepared than previous generations for the prospect of longer working lives. For China to avoid becoming stuck in the middle-income stage, these efforts will need to increase not only high school and university education levels, but also education quality. For example, rural labourers transferring to urban areas are often insufficiently qualified to fill available vacancies, while many university graduates cannot find jobs (Cai and Wang 2007). In general, China must ensure that its diminished number of young have abundant human capital so as to safeguard their ability to learn as they age (Cai 2012).

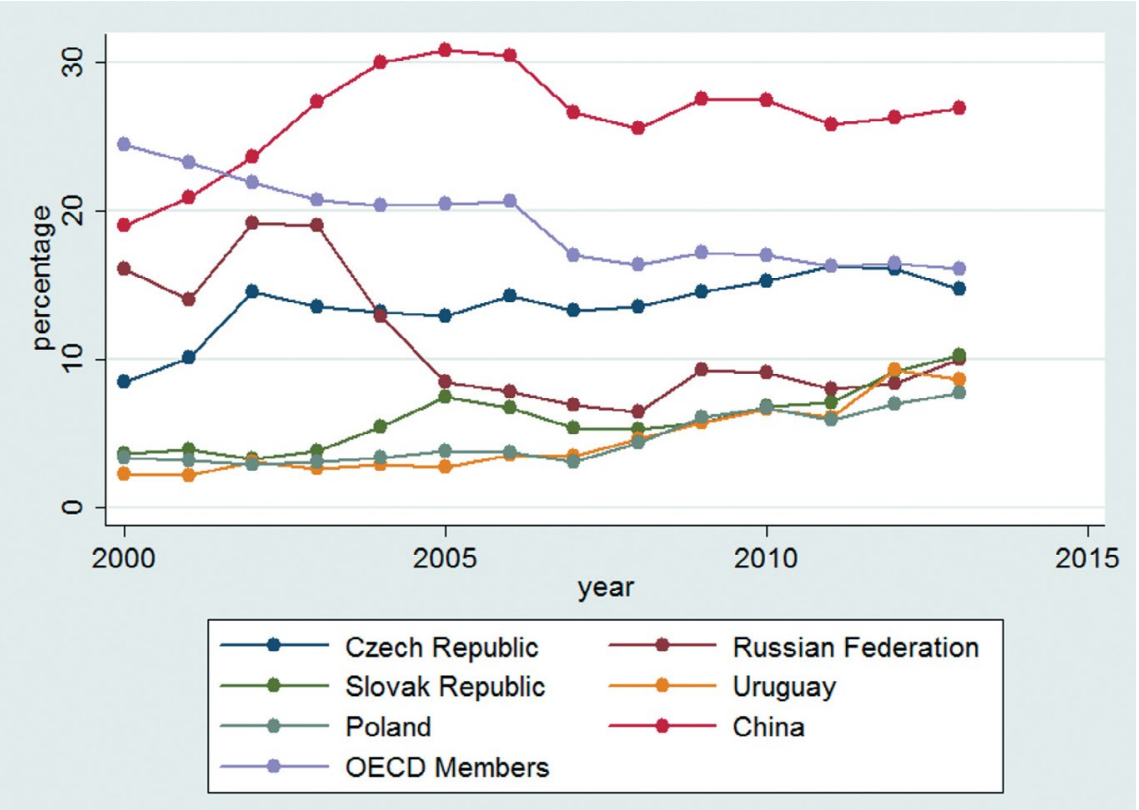

Figure 10.7 High-tech exports as a percentage of manufactured exports in China compared with countries that were PO before RO and OECD average Source: World Bank (2015). 


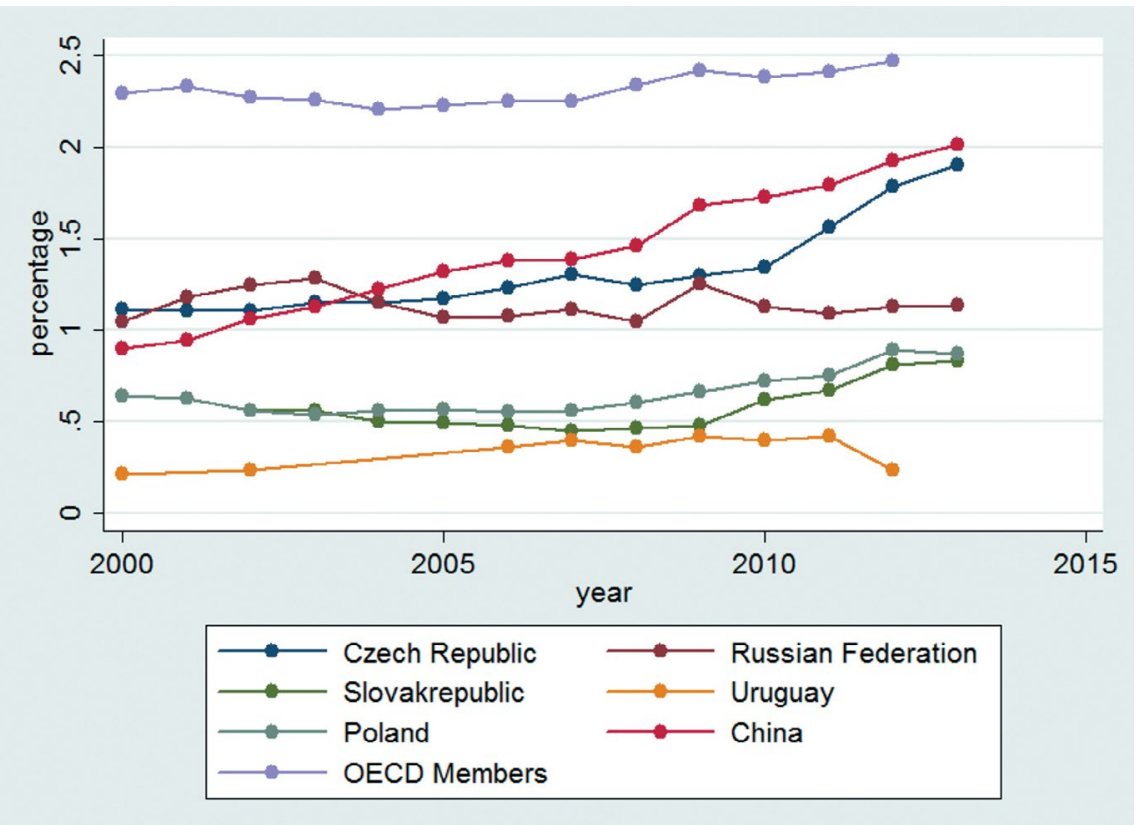

Figure 10.8 Research and development expenditure as a percentage of GDP in China compared with countries that were PO before RO and OECD average Source: World Bank (2015).

With regard to Eichengreen et al.'s (2014) second necessary factor for successful income transition - a relatively high share of high-technology products within exports - China is in fact a positive outlier in terms of having high levels of manufactured exports and high investment in high-tech industries, even compared with the OECD. It has been so since soon after joining the World Trade Organization in 2001 (Figure 10.7). Such are the scale and success of China's high-tech exports that they are found to have displaced other middleincome country competitor exports, including those of India, Brazil and Mexico as well as Malaysia, Thailand and Vietnam (Pham et al. 2016). Using research and development (R\&D) expenditure as a percentage of GDP to serve as an indicator of the potential to export such products in future. China has already surpassed the level of R\&D expenditure of all countries that recently realised high per capita incomes while also having an ageing population (Figure 10.8).

These simple comparisons suggest that China may have a reasonable chance of navigating from PO to RO, as have Uruguay, the Czech Republic, the Russian Federation and the Slovakia Republic since 1990. Further, as other countries in East Asia and other regions seek to make the same transition in future, China's potentially more imminent success or failure will set an important precedent- 
that a declining total fertility rate and rising life expectancy in the early phase of a development transition need not inhibit advanced economic development and, in fact, could even support it.

\section{Discussion}

For three decades, Chinese policymakers have sought to best utilise China's now fading demographic dividend. That effort built on fears about the adverse economic development effects of the premature arrival of the turning point at which the national workforce share begins to decline. Underlying these fears was the fact that China, unlike its North-East Asian neighbours, would get old before getting rich - the related pressures of which on output per person would inhibit transition to high-income livelihoods.

This chapter returned to the starting point of those fears: a 1986 paper by Renmin University demographer Wu Canping. In a first in the literature, it has extended Wu's (1986) idea of getting old before getting rich to the full four-state framework that it implies. In so doing, we shed a different but related light on China's ageing population challenge. For example, we identified that China is just one of some 30 countries that is getting old before it gets rich. Also, in recent years among countries without oil wealth, the developing countries with ageing populations were the ones most likely to ascend into the high-income group. China aims to do the same. If it succeeds, it will join the four identified countries that have already achieved this progression since 1990: Uruguay, the Czech Republic, the Russian Federation and the Slovakia Republic.

In addition to drawing comparative attention to China's relative transition prospects given its income and ageing conditions, this chapter draws attention to issues around the potential for ageing populations to have very divergent economic effects - in two countries that happen to have the same share of aged population (and the same ageing rate) but are otherwise fundamentally different. In this vein, the 'old' across countries are endogenously systematically different in terms of, for example, relative pension entitlements, share of asset ownership, accrued entitlements and access to publicly funded services through retirement. In addition, the broader macroeconomic conditions around ageing populations also vary - for example, with respect to accumulated public debt per capita and whether there is a rising or falling share of national income accruing to the working-age population. Importantly, too, older populations in different countries enjoy very different relative political powers that can be employed to preserve their benefits. As Wu (1986) implicitly found, ageing population economics extend far beyond a simple linear function of the share of the population aged over 65 . 
Here we hope to have encouraged a more nuanced understanding of the broader economic and political economy context of China's ageing population challenge. By implication, this also serves similarly for other countries. For all countries with an ageing population it is important to heed the additional driver of population ageing after increasing life expectancy and decreasing fertility rates: past variations in birth and death rates (Bloom et al. 2010). The population cohort born in China before the implementation of strict family planning in the late 1970s is an example. The baby boom that resulted from increased fertility in rich countries after World War II is another. These examples reflect the demographic ebb and flow and its non-synchronicity across countries (İmrohoroğlu 2007).

The specific contribution of Wu (1986) here and in the case of China was to highlight the importance of the timing of the demographic ebb and flow around national wealth accumulation and to factor the appropriate consequences into intergenerational economic planning. In China, the population is getting old before getting rich. By comparison, Japan, South Korea and most of the rest of the OECD had relatively young populations when they became rich.

In practice, this difference means that even were China to enter the high-income grouping soon, its large numbers of aged people would nonetheless have lived the majority of their lives as residents of a poor country - and their benefits are likely to have accumulated accordingly. By comparison, the emerging large cohort of those aged over 65 in rich countries has spent most of their lifespan relatively well placed economically, domestically and internationally - so much so that some researchers have voiced fears that this will lead to 'a self-centred generation just sucking down all the resources' (Dychtwald 1999, cited in Bloom et al. 2010).

In this context and to our knowledge, there are no studies directly comparing the potentially very divergent economic consequences of population ageing in GOBR versus GOAR economies. It is possible this missing more nuanced approach to ageing populations and economics research risks conceptually underestimating the potential ageing risks in rich-country democracies, and similarly miscalculating the ageing challenges confronting China and other GOBR economies. Cai (2012), for example, has pointed out that China has room to utilise the gap between it and developed countries to sustain economic growth. In contrast, OECD countries face population ageing amid the uncertainty of pushing the economic frontier while also affording the much more extensive old age dependency entitlements that the older cohort in these populations has accumulated.

In China's case, Li (2006) fears that the time when the youth dependency rate exceeds the elderly dependency rate (around 2030) will morph China into an 'ageing society'. Understanding these fears could be supported by further, parallel investigation of a newer, herein raised, notion of an 'ageing 
economy'. Development of the concept would seek to capture the dynamic economic consequences of the relative share of the economy accruing to the less economically active population aged over 65, and estimate the dynamic economic impact accordingly. This would vary across countries according to the factors discussed herein, and would help to form a useful indicator of the risks that ageing populations may pose to the dampening of economic activity - right at a time when the opposite is required to sustain related costs.

\section{Conclusion}

For more than three decades, China has been actively preparing for population ageing around the idea that it will get old before getting rich. In the related debate both within and outside China, it has consistently been assumed that China's ageing population conditions are uniquely adverse. In this chapter, we studied China's ageing in a cross-country context and identified that China is an outlier only for the total number, but not for the proportion, of its elderly people. It is not, however, alone in 'getting old before getting rich', and nor has that challenge proven insurmountable in recent history. We herein identified four countries that got rich after getting old. China seeks to achieve the same.

Towards that goal, it would be timely to explore more deeply whether there are in fact advantages to getting old before getting rich - and to make the most of them. Chinese researchers have, for example, highlighted that China is still experiencing catch-up growth to support its transition with an ageing population. China also has relative freedom to define its ageing population entitlements in an ageing context. Against expectation, this could be the foundation for their sustainability. GOAR countries, in comparison, must manage ageing populations amid legacy ageing institutions that were shaped in a period of high relative wealth but much smaller ageing population shares and shorter life expectancies. GOBR countries such as China may in fact experience circumstances of much easier political economy and fiscal sustainability in which to manage the ageing demographic transition.

China's government has set a goal that by about 2020, the country's per capita income will reach high-income levels - set in 2014 at more than $\$ 12,736$ per capita. China's GDP per capita in 2014 was $\$ 7,590$. China's ability to navigate that transition smoothly over the coming decades will depend on how it can increase output per worker despite a declining workforce share and while losing its wage-related advantages. Via education and technological upgrading in particular, and in its long-standing frontier coastal economic environments, so far, China is broadly succeeding. 
Importantly, China's prospects for getting rich after getting old-like those of the other countries in the same stage of demographic/income transition-may also be enhanced through a more nuanced and dynamic understanding of the factors underlying such transitions over time. A more dynamic understanding of the impact of ageing populations on economies is also likely to be facilitated by a deliberate separation of the demographic notion of an ageing population from the economic context and dynamic effects of ageing populations. It may not be that an ageing population explicitly slows growth, but rather that this happens when an ageing population is positioned to induce effects that instead become symptomatic of the more dynamic and worrying nascent notion of an 'ageing economy'.

Further research is required. Studies that can better identify the prospectively divergent economic impacts of different ageing populations may better inform not only policymaking in developing countries with ageing populations, but also rich countries navigating the different yet potentially no less ominous challenges of getting old after getting rich. More research in this direction may in fact serve to support enhanced growth in both.

\section{References}

Barro, R. J. and Lee, J. W. (2013), A new data set of educational attainment in the world, 1950-2010, Journal of Development Economics, 104: 184-198.

Bloom, D. E., Canning, D. and Fink, G. (2010), Implications of population ageing for economic growth, Oxford Review of Economic Policy, 26(4): 583-612.

Cai, F. (2010), Demographic transition, demographic dividend, and Lewis turning point in China, China Economic Journal, 3(2): 107-119.

Cai, F. (2012), The coming demographic impact on China's growth: The age factor in the middle-income trap, Asian Economic Papers, 11(1): 95-111.

Cai, F. and Wang, M. (2007), How will population aging affect economic growth?, China Economist, [English edn], (1): 86-94.

Calvo, G. and Reinhart, C. (2002), Fear of floating, Quarterly Journal of Economics, 107(2) (May): 379-408.

Clark, R., Kreps, J. and Spengler, J. (1978), Economics of aging: A survey, Journal of Economic Literature, 16(3): 919-962.

Day, C. and Dowrick, S. (2004), Ageing economics: Human capital, productivity and fertility, Agenda: A Journal of Policy Analysis and Reform, 11(1): 3-20. 
Eichengreen, B., Park, D. and Shin, K. (2014), Growth slowdowns redux, Japan and the World Economy, 32: 65-84.

Eisele, F. R. (ed.) (1974), Political consequences of aging, Annals of the American Academy of Political and Social Sciences, 415 (September).

Garnaut, R. (2010), Macro-economic implications of the turning point, China Economic Journal, 3(2): 181-190.

Golley, J. and Tyers, R. (2012), Demographic dividends, dependencies, and economic growth in China and India, Asian Economic Papers, 11(3): 1-26.

Guillermo, A., Carmen, R. and Guillermo, C. (2002), Fear of floating, The Quarterly Journal of Economics, 117(2): 379-408. doi: 10.1162/003355302753650274.

$\mathrm{Hu}$, A., Liu, S. and Ma, Z. (2012), Population aging, population growth and economic growth: Evidence from China's provincial panel data, Population Research, 36(3): 14-26.

İmrohoroğlu, A. (2007), Consequences of demographic change for rates of returns to capital, and the distribution of wealth and welfare: A comment, Journal of Monetary Economics, 54(1): 88-91.

International Labour Organization (ILO) (2009), Ageing societies: The benefits, and the costs, of living longer, World of Work, 67 (December). Available from: ilo.org/global/publications/magazines-and-journals/world-of-workmagazine/articles/WCM_041965/lang--en/index.htm.

International Monetary Fund (IMF) (2015), World economic outlook: Uneven growth-Short and long-term factors, April, Washington, DC: IMF. Available from: imf.org/external/pubs/ft/weo/2015/01/index.htm.

Johnston, L. (2012), Getting old after getting rich: Comparing China with Japan, East Asia Forum, 22 December. Available from: eastasiaforum. org/2012/12/22/getting-old-after-getting-rich-comparing-china-with-japan/.

Li, J. (2006), Is China getting old before getting rich?, Population Research, 30(6): 23-37.

Lutz, W., Sanderson, W. and Scherbov, S. (2008), The coming acceleration of global population ageing, Nature, 451(7179): 716-719.

Minami, R. (1968), The turning point in the Japanese economy, The Quarterly Journal of Economics, 82(3): 380-402.

Onofri, P. (2004), The economics of an ageing population, Cheltenham, UK: Edward Elgar. 
Park, D., Lee, S. H. and Mason, A. (eds) (2012), Aging, economic growth, and oldage security in Asia, Cheltenham, UK: Edward Elgar.

Pham, C. S., Nguyen, X., Sgro, P. and Tang, X. (2016), Has China displaced its competitors in high-tech trade?, World Economy, 1(2016). doi: 10.1111/ twec. 12390.

Powell, J. L. and Cook, I. G. (2009), Global ageing in comparative perspective: A critical discussion, International Journal of Sociology and Social Policy, 29(7-8): 388-400.

Sanderson, W. C. and Scherbov, S. (2007), A new perspective on population aging, Demographic Research, 16(2): 27-58.

Siegel, J. S. (1980), On the demography of aging, Demography, 17(4): 345-364.

Stephenson, J. and Scobie, G. (2002), The economics of population ageing, No. 02/04, Wellington: New Zealand Treasury.

UNDATA (2016), Total fertility rate, Glossary, UNDATA. Available from: data.un.org/Glossary.aspx?q=total+fertility+rate.

United Nations (UN) (1956), The aging of populations and its social and economic implications, Population Studies No. 26, New York: United Nations.

United Nations (UN) (2002), World population ageing: 1950-2050, Department of Economic and Social Affairs, New York: United Nations. Available from: un.org/ esa/population/publications/worldageing 19502050/pdf/7introduction.pdf.

United Nations (UN) (2015), World population prospects: The 2015 revision, Population Division, Department of Economic and Social Affairs, New York: United Nations.

United Nations Population Fund (UNFPA) (2015), Demographic dividend, New York: UNFPA. Available from: unfpa.org/demographic-dividend.

Wang, D., Cai, F. and Zhang, X. (2004), Saving and growth effects of demographic transition, Population Research, (5): 2-11.

World Bank (2015), World development indicators, Washington, DC: The World Bank. Available from: data.worldbank.org/data-catalog/world-developmentindicators.

World Bank (2016), Live long and prosper? Aging in East Asia Pacific, Washington, DC: The World Bank. Available from: openknowledge.worldbank.org/ bitstream/handle/10986/23133/9781464804694.pdf. 
Wu, C. (1986), Discussions on population ageing, Shenyang: Liaoning People's Publishing House.

$\mathrm{Wu}, \mathrm{C}$. and Du, P. (2006), Population ageing in China: Changes and challenges, Beijing: China Population Publishing House.

\section{Appendix 10.1}

Table A10.1 Country allocation by extended Wu framework typology, 2014

\begin{tabular}{|c|c|c|c|c|c|}
\hline Country & 1990 & 2000 & 2005 & 2010 & 2014 \\
\hline Afghanistan & & & 4 & 4 & 4 \\
\hline Albania & 4 & 2 & 2 & 2 & 2 \\
\hline Algeria & 4 & 4 & 4 & 4 & 4 \\
\hline Andorra & & 3 & 3 & 3 & 3 \\
\hline Angola & 4 & 4 & 4 & 4 & 4 \\
\hline Antigua and Barbuda & 1 & 1 & 1 & 1 & 1 \\
\hline Argentina & 2 & 2 & 2 & 2 & 2 \\
\hline Armenia & 4 & 2 & 2 & 2 & 2 \\
\hline Aruba & & 1 & 1 & 1 & 1 \\
\hline Australia & 1 & 1 & 1 & 1 & 1 \\
\hline Austria & 1 & 1 & 1 & 1 & 1 \\
\hline Azerbaijan & 4 & 4 & 4 & 4 & 4 \\
\hline Bahamas, The & 3 & 3 & 3 & 3 & 1 \\
\hline Bahrain & 3 & 3 & 3 & 3 & 3 \\
\hline Bangladesh & 4 & 4 & 4 & 4 & 4 \\
\hline Barbados & 1 & 1 & 1 & 1 & 1 \\
\hline Belarus & 2 & 2 & 2 & 2 & 2 \\
\hline Belgium & 1 & 1 & 1 & 1 & 1 \\
\hline Belize & 4 & 4 & 4 & 4 & 4 \\
\hline Benin & 4 & 4 & 4 & 4 & 4 \\
\hline Bhutan & 4 & 4 & 4 & 4 & 4 \\
\hline Bolivia & 4 & 4 & 4 & 4 & 4 \\
\hline Bosnia and Herzegovina & & 2 & 2 & 2 & 2 \\
\hline Botswana & 4 & 4 & 4 & 4 & 4 \\
\hline Brazil & 4 & 4 & 4 & 4 & 2 \\
\hline Brunei Darussalam & 3 & 3 & 3 & 3 & 3 \\
\hline Bulgaria & 2 & 2 & 2 & 2 & 2 \\
\hline
\end{tabular}


China's New Sources of Economic Growth (I)

\begin{tabular}{|c|c|c|c|c|c|}
\hline Country & 1990 & 2000 & 2005 & 2010 & 2014 \\
\hline Burkina Faso & 4 & 4 & 4 & 4 & 4 \\
\hline Burundi & 4 & 4 & 4 & 4 & 4 \\
\hline Cape Verde & 4 & 4 & 4 & 4 & 4 \\
\hline Cambodia & & 4 & 4 & 4 & 4 \\
\hline Cameroon & 4 & 4 & 4 & 4 & 4 \\
\hline Canada & 1 & 1 & 1 & 1 & 1 \\
\hline Caribbean small states & 4 & 4 & 2 & 2 & 2 \\
\hline Central African Republic & 4 & 4 & 4 & 4 & 4 \\
\hline Chad & 4 & 4 & 4 & 4 & 4 \\
\hline Channel Islands & & 1 & 1 & 1 & 1 \\
\hline Chile & 4 & 2 & 2 & 1 & 1 \\
\hline China & 4 & 4 & 2 & 2 & 2 \\
\hline Colombia & 4 & 4 & 4 & 4 & 4 \\
\hline Comoros & 4 & 4 & 4 & 4 & 4 \\
\hline Congo, Dem. Rep. & 4 & 4 & 4 & 4 & 4 \\
\hline Congo, Rep. & 4 & 4 & 4 & 4 & 4 \\
\hline Costa Rica & 4 & 4 & 4 & 2 & 2 \\
\hline Cote d'Ivoire & 4 & 4 & 4 & 4 & 4 \\
\hline Croatia & & 2 & 1 & 1 & 1 \\
\hline Cuba & 2 & 2 & 2 & 2 & 2 \\
\hline Cyprus & 1 & 1 & 1 & 1 & 1 \\
\hline Czech Republic & 2 & 2 & 1 & 1 & 1 \\
\hline Denmark & 1 & 1 & 1 & 1 & 1 \\
\hline Djibouti & 4 & 4 & 4 & 4 & 4 \\
\hline Dominican Republic & 4 & 4 & 4 & 4 & 4 \\
\hline Ecuador & 4 & 4 & 4 & 4 & 4 \\
\hline Egypt, Arab Rep. & 4 & 4 & 4 & 4 & 4 \\
\hline El Salvador & 4 & 4 & 4 & 2 & 2 \\
\hline Equatorial Guinea & 4 & 4 & 3 & 3 & 3 \\
\hline Eritrea & & 4 & 4 & 4 & 4 \\
\hline Estonia & & 2 & 1 & 1 & 1 \\
\hline Ethiopia & 4 & 4 & 4 & 4 & 4 \\
\hline Fiji & 4 & 4 & 4 & 4 & 4 \\
\hline Finland & 1 & 1 & 1 & 1 & 1 \\
\hline France & 1 & 1 & 1 & 1 & 1 \\
\hline
\end{tabular}


10. Getting Rich after Getting Old

\begin{tabular}{|c|c|c|c|c|c|}
\hline Country & 1990 & 2000 & 2005 & 2010 & 2014 \\
\hline French Polynesia & 3 & 3 & 3 & 3 & 1 \\
\hline Gabon & 3 & 4 & 4 & 4 & 4 \\
\hline Gambia, The & 4 & 4 & 4 & 4 & 4 \\
\hline Georgia & 2 & 2 & 2 & 2 & 2 \\
\hline Germany & 1 & 1 & 1 & 1 & 1 \\
\hline Ghana & 4 & 4 & 4 & 4 & 4 \\
\hline Greece & 1 & 1 & 1 & 1 & 1 \\
\hline Grenada & 2 & 2 & 2 & 2 & 2 \\
\hline Guatemala & 4 & 4 & 4 & 4 & 4 \\
\hline Guinea & 4 & 4 & 4 & 4 & 4 \\
\hline Guinea-Bissau & 4 & 4 & 4 & 4 & 4 \\
\hline Guyana & 4 & 4 & 4 & 4 & 4 \\
\hline Haiti & & 4 & 4 & 4 & 4 \\
\hline Honduras & 4 & 4 & 4 & 4 & 4 \\
\hline Hong Kong SAR, China & 1 & 1 & 1 & 1 & 1 \\
\hline Hungary & & 2 & 1 & 1 & 1 \\
\hline Iceland & 1 & 1 & 1 & 1 & 1 \\
\hline India & 4 & 4 & 4 & 4 & 4 \\
\hline Indonesia & 4 & 4 & 4 & 4 & 4 \\
\hline Iran, Islamic Rep. & 4 & 4 & 4 & 4 & 4 \\
\hline Iraq & 3 & & 4 & 4 & 4 \\
\hline Ireland & 1 & 1 & 1 & 1 & 1 \\
\hline Israel & 1 & 1 & 1 & 1 & 1 \\
\hline Italy & 1 & 1 & 1 & 1 & 1 \\
\hline Jamaica & 2 & 2 & 2 & 2 & 2 \\
\hline Japan & 1 & 1 & 1 & 1 & 1 \\
\hline Jordan & 4 & 4 & 4 & 4 & 4 \\
\hline Kazakhstan & 4 & 4 & 2 & 4 & 4 \\
\hline Kenya & 4 & 4 & 4 & 4 & 4 \\
\hline Kiribati & 4 & 4 & 4 & 4 & 4 \\
\hline Korea, Rep. & 3 & 1 & 1 & 1 & 1 \\
\hline Kosovo & & & & 4 & 4 \\
\hline Kuwait & 3 & 3 & 3 & 3 & 3 \\
\hline Kyrgyz Republic & 4 & 4 & 4 & 4 & 4 \\
\hline Lao PDR & 4 & 4 & 4 & 4 & 4 \\
\hline
\end{tabular}


China's New Sources of Economic Growth (I)

\begin{tabular}{|c|c|c|c|c|c|}
\hline Country & 1990 & 2000 & 2005 & 2010 & 2014 \\
\hline Latvia & & 2 & 2 & 2 & 1 \\
\hline Lebanon & 4 & 2 & 2 & 2 & 2 \\
\hline Lesotho & 4 & 4 & 4 & 4 & 4 \\
\hline Liberia & 4 & 4 & 4 & 4 & 4 \\
\hline Libya & 3 & 4 & 4 & 3 & 4 \\
\hline Lithuania & & & 2 & 1 & 1 \\
\hline Luxembourg & 1 & 1 & 1 & 1 & 1 \\
\hline Macau SAR, China & 3 & 1 & 1 & 1 & 1 \\
\hline Macedonia, FYR & 2 & 2 & 2 & 2 & 2 \\
\hline Madagascar & 4 & 4 & 4 & 4 & 4 \\
\hline Malawi & 4 & 4 & 4 & 4 & 4 \\
\hline Malaysia & 4 & 4 & 4 & 4 & 4 \\
\hline Maldives & 4 & 4 & 4 & 4 & 4 \\
\hline Mali & 4 & 4 & 4 & 4 & 4 \\
\hline Malta & 1 & 1 & 1 & 1 & 1 \\
\hline Mauritania & 4 & 4 & 4 & 4 & 4 \\
\hline Mauritius & 4 & 4 & 4 & 2 & 2 \\
\hline Mexico & 4 & 4 & 4 & 4 & 4 \\
\hline Micronesia, Fed. States & 4 & 4 & 4 & 4 & 4 \\
\hline Moldova & 2 & 2 & 2 & 2 & 2 \\
\hline Mongolia & 4 & 4 & 4 & 4 & 4 \\
\hline Montenegro & & 2 & 2 & 2 & 2 \\
\hline Morocco & 4 & 4 & 4 & 4 & 4 \\
\hline Mozambique & 4 & 4 & 4 & 4 & 4 \\
\hline Myanmar & & & & & 4 \\
\hline Namibia & 4 & 4 & 4 & 4 & 4 \\
\hline Nepal & 4 & 4 & 4 & 4 & 4 \\
\hline Netherlands & 1 & 1 & 1 & 1 & 1 \\
\hline New Caledonia & 3 & 3 & 3 & 1 & 2 \\
\hline New Zealand & 1 & 1 & 1 & 1 & 1 \\
\hline Nicaragua & 4 & 4 & 4 & 4 & 4 \\
\hline Niger & 4 & 4 & 4 & 4 & 4 \\
\hline Nigeria & 4 & 4 & 4 & 4 & 4 \\
\hline North America & 1 & 1 & 1 & 1 & 1 \\
\hline Norway & 1 & 1 & 1 & 1 & 1 \\
\hline
\end{tabular}


10. Getting Rich after Getting Old

\begin{tabular}{|c|c|c|c|c|c|}
\hline Country & 1990 & 2000 & 2005 & 2010 & 2014 \\
\hline Pakistan & 4 & 4 & 4 & 4 & 4 \\
\hline Panama & 4 & 4 & 4 & 4 & 2 \\
\hline Papua New Guinea & 4 & 4 & 4 & 4 & 4 \\
\hline Paraguay & 4 & 4 & 4 & 4 & 4 \\
\hline Peru & 4 & 4 & 4 & 4 & 4 \\
\hline Philippines & 4 & 4 & 4 & 4 & 4 \\
\hline Poland & 2 & 2 & 2 & 1 & 1 \\
\hline Portugal & 1 & 1 & 1 & 1 & 1 \\
\hline Puerto Rico & 1 & 1 & 1 & 1 & 1 \\
\hline Qatar & 3 & 3 & 3 & 3 & 3 \\
\hline Romania & 2 & 2 & 2 & 2 & 2 \\
\hline Russian Federation & 2 & 2 & 2 & 2 & 1 \\
\hline Rwanda & 4 & 4 & 4 & 4 & 4 \\
\hline Samoa & 4 & 4 & 4 & 4 & 4 \\
\hline Sao Tome and Principe & & 4 & 4 & 4 & 4 \\
\hline Saudi Arabia & 3 & 4 & 3 & 3 & 3 \\
\hline Senegal & 4 & 4 & 4 & 4 & 4 \\
\hline Serbia & & 2 & 2 & 2 & 2 \\
\hline Seychelles & 4 & 2 & 1 & 2 & 3 \\
\hline Sierra Leone & 4 & 4 & 4 & 4 & 4 \\
\hline Singapore & 3 & 1 & 1 & 1 & 1 \\
\hline Slovakia Republic & 2 & 2 & 1 & 1 & 1 \\
\hline Slovenia & & 1 & 1 & 1 & 1 \\
\hline Small states & 4 & 4 & 4 & 4 & 4 \\
\hline Solomon Islands & 4 & 4 & 4 & 4 & 4 \\
\hline Somalia & 4 & & & & \\
\hline South Africa & 4 & 4 & 4 & 4 & 4 \\
\hline South Asia & 4 & 4 & 4 & 4 & 4 \\
\hline South Sudan & & & & 4 & 4 \\
\hline Spain & 1 & 1 & 1 & 1 & 1 \\
\hline Sri Lanka & 4 & 4 & 4 & 2 & 2 \\
\hline St Lucia & 2 & 2 & 2 & 2 & 2 \\
\hline St Vincent and the Grenadines & 4 & 4 & 2 & 4 & 2 \\
\hline Sudan & 4 & 4 & 4 & 4 & 4 \\
\hline Suriname & 4 & 4 & 4 & 4 & 4 \\
\hline
\end{tabular}


China's New Sources of Economic Growth (I)

\begin{tabular}{|c|c|c|c|c|c|}
\hline Country & 1990 & 2000 & 2005 & 2010 & 2014 \\
\hline Swaziland & 4 & 4 & 4 & 4 & 4 \\
\hline Sweden & 1 & 1 & 1 & 1 & 1 \\
\hline Switzerland & 1 & 1 & 1 & 1 & 1 \\
\hline Syrian Arab Republic & 4 & 4 & 4 & 4 & 4 \\
\hline Tajikistan & 4 & 4 & 4 & 4 & 4 \\
\hline Tanzania & 4 & 4 & 4 & 4 & 4 \\
\hline Thailand & 4 & 4 & 2 & 2 & 2 \\
\hline Timor-Leste & & 4 & 4 & 4 & 4 \\
\hline Togo & 4 & 4 & 4 & 4 & 4 \\
\hline Tonga & 4 & 4 & 4 & 4 & 4 \\
\hline Trinidad and Tobago & 4 & 4 & 1 & 1 & 1 \\
\hline Tunisia & 4 & 4 & 2 & 2 & 2 \\
\hline Turkey & 4 & 4 & 4 & 2 & 2 \\
\hline Turkmenistan & 4 & 4 & 4 & 4 & 4 \\
\hline Uganda & 4 & 4 & 4 & 4 & 4 \\
\hline Ukraine & 2 & 2 & 2 & 2 & 2 \\
\hline United Arab Emirates & 3 & 3 & 3 & 3 & 3 \\
\hline United Kingdom & 1 & 1 & 1 & 1 & 1 \\
\hline United States & 1 & 1 & 1 & 1 & 1 \\
\hline Uruguay & 2 & 2 & 2 & 1 & 1 \\
\hline Uzbekistan & 4 & 4 & 4 & 4 & 4 \\
\hline Vanuatu & 4 & 4 & 4 & 4 & 4 \\
\hline Venezuela, RB & 4 & 4 & 4 & 3 & 3 \\
\hline Vietnam & 4 & 4 & 4 & 4 & 4 \\
\hline West Bank and Gaza & & 4 & 4 & 4 & 4 \\
\hline Yemen, Rep. & 4 & 4 & 4 & 4 & 4 \\
\hline Zambia & 4 & 4 & 4 & 4 & 4 \\
\hline Zimbabwe & 4 & 4 & 4 & 4 & 4 \\
\hline
\end{tabular}

Note: Blank cells mean there are no data for the country. 
Table A10.2 Population over-65 years descriptive statistics: Year and ageing transition category

\begin{tabular}{|l|l|r|r|r|r|}
\hline Population over 65 & & $\mathbf{1 9 9 0}$ & $\mathbf{2 0 0 0}$ & $\mathbf{2 0 1 0}$ & $\mathbf{2 0 1 4}$ \\
\hline \multirow{4}{*}{ Rich and old } & Mean & 12.62 & 13.11 & 14.59 & 15.99 \\
\cline { 2 - 6 } & Std. & 2.46 & 3.20 & 3.59 & 3.98 \\
\cline { 2 - 6 } & Max. & 17.78 & 18.07 & 22.94 & 25.71 \\
\cline { 2 - 6 } & Min. & 8.05 & 7.08 & 7.20 & 7.12 \\
\hline \multirow{5}{*}{ Rich and youth-filled } & Mean & 3.77 & 3.15 & 3.16 & 3.41 \\
\cline { 2 - 6 } & Std. & 1.80 & 1.80 & 1.96 & 2.14 \\
\cline { 2 - 6 } & Max. & 6.71 & 5.95 & 6.95 & 6.83 \\
\cline { 2 - 6 } & Min. & 1.17 & 1.06 & 0.69 & 1.04 \\
\hline \multirow{5}{*}{ Poor and old } & Mean & 9.81 & 11.42 & 10.85 & 11.08 \\
\cline { 2 - 6 } & Std. & 1.85 & 2.90 & 3.52 & 3.52 \\
\cline { 2 - 6 } & Max. & 13.16 & 16.58 & 18.37 & 19.73 \\
\cline { 2 - 6 } & Min. & 7.20 & 7.07 & 7.03 & 7.15 \\
\hline \multirow{5}{*}{ Poor and youth-filled } & Mean & 3.77 & 4.00 & 4.09 & 4.12 \\
\cline { 2 - 6 } & Std. & 0.99 & 1.22 & 1.27 & 1.27 \\
\cline { 2 - 6 } & Max. & 6.69 & 6.93 & 6.80 & 6.76 \\
\cline { 2 - 6 } & Min. & 1.91 & 2.27 & 2.31 \\
\hline
\end{tabular}

Table A10.3 GDP per capita descriptive statistics: Year and ageing transition category

\begin{tabular}{|l|l|r|r|r|r|}
\hline GDP per capita & & $\mathbf{1 9 9 0}$ & $\mathbf{2 0 0 0}$ & $\mathbf{2 0 1 0}$ & $\mathbf{2 0 1 4}$ \\
\hline \multirow{4}{*}{ Rich and old } & Mean & $19,202.64$ & $23,591.87$ & $35,669.88$ & $37,153.97$ \\
\cline { 2 - 6 } & Std. & $8,476.86$ & $10,059.05$ & $20,076.97$ & $21,141.06$ \\
\cline { 2 - 6 } & Max. & $38,332.15$ & $48,826.55$ & $102,863.10$ & $97,363.09$ \\
\cline { 2 - 6 } & Min. & $6,325.24$ & $10,094.76$ & $11,938.22$ & $12,735.92$ \\
\hline \multirow{5}{*}{ Rich and youth-filled } & Mean & $11,926.88$ & $20,472.37$ & $27,683.47$ & $35,187.51$ \\
\cline { 2 - 6 } & Std. & $5,521.09$ & $7,835.89$ & $17,566.21$ & $27,479.56$ \\
\cline { 2 - 6 } & Max. & $2,7989.3$ & $34,207.54$ & $70,870.23$ & $97,518.61$ \\
\cline { 2 - 6 } & Min. & $6,250.64$ & $12,579.60$ & $11,933.78$ & $15,359.18$ \\
\hline \multirow{5}{*}{ Poor and old } & Mean & $2,395.36$ & $3,390.68$ & $6,259.35$ & $7,189.90$ \\
\cline { 2 - 6 } & Std. & 898.73 & $2,262.03$ & $2,814.76$ & $3,001.91$ \\
\cline { 2 - 6 } & Max. & $4,318.77$ & $7,669.27$ & $11,379.24$ & $12,568.57$ \\
\cline { 2 - 6 } & Min. & 972.09 & 354.00 & $1,631.54$ & $2,233.77$ \\
\hline \multirow{5}{*}{ Poor and youth-filled } & Mean & $1,032.69$ & $1,451.07$ & $2,631.43$ & $2,950.55$ \\
\cline { 2 - 6 } & Std. & 930.25 & $1,629.32$ & $2,493.88$ & $2,773.73$ \\
\cline { 2 - 6 } & Max. & $5,265.50$ & $8,808.88$ & $11,124.08$ & $12,276.39$ \\
\cline { 2 - 6 } & Min. & 98.03 & 124.05 & 214.88 & 255.04 \\
\hline
\end{tabular}


This text is taken from China's New Sources of Economic Growth: Reform, resources and climate change, Volume 1, edited by Ligang Song, Ross Garnaut, Cai Fang \& Lauren Johnston, published 2016 by ANU Press, The Australian National University, Canberra, Australia. 